University of Nebraska - Lincoln

DigitalCommons@University of Nebraska - Lincoln

Faculty Papers and Publications in Animal

Science

Animal Science Department

January 1969

\title{
GROWTH OF YORKSHIRE SUCKLING PIGS
}

W. F. Gipp

Cornell University

W. G. Pond

Cornell University

L. Dale Van Vleck

University of Nebraska-Lincoln, dvan-vleck1@unl.edu

P. D. Miller

Cornell University

Follow this and additional works at: https://digitalcommons.unl.edu/animalscifacpub

Part of the Animal Sciences Commons

Gipp, W. F.; Pond, W. G.; Van Vleck, L. Dale; and Miller, P. D., "GROWTH OF YORKSHIRE SUCKLING PIGS" (1969). Faculty Papers and Publications in Animal Science. 326.

https://digitalcommons.unl.edu/animalscifacpub/326

This Article is brought to you for free and open access by the Animal Science Department at DigitalCommons@University of Nebraska - Lincoln. It has been accepted for inclusion in Faculty Papers and Publications in Animal Science by an authorized administrator of DigitalCommons@University of Nebraska - Lincoln. 
Gipp, W. F., Pond, W. G., Van Vleck, L. D. and Miller, P. D. 1969. Growth of Yorkshire suckling pigs. Journal of Animal Science 29:330-331.

Abstract: The birthweights and daily liveweights for 87 male and 99 female pigs reared under drylot conditions were obtained over a 3-week period and used to construct a growth curve for the very young male and female pig. Analysis of variance was used to test litter and sex main effects and the litter $\mathrm{x}$ sex interaction effect on liveweight. The daily standard deviations of the 186 pig sample were calculated and are presented in graphic form. No significant difference between the growth of male and female pigs of this young age were found. The average birth and first-, second- and thirdweek liveweights and standard deviations were 1.1 $\pm .12,2.0 \pm .27,3.3 \pm .48$ and $5.0 \pm .74 \mathrm{~kg}$., respectively, for the pooled male and female observations. Analysis of variance of the data indicated significant differences in growth due to litter effects for all of the 21 days of the experiment, but there was generally no significant difference due to sex and no sex x litter interaction.

Copyright $\odot 1969$ American Society of Animal Science. Used by permission. 


\title{
GROWTH OF YORKSHIRE SUCKLING PIGS
}

\author{
W. F. Gipp, W. G. Pond, L. D. Van Vleck and P. D. Mrller ${ }^{1}$ \\ Cornell University, Ithaca, New York
}

\begin{abstract}
$\mathrm{A}$ LTHOUGH growth is commonly used as a criterion for evaluating performance, available data on normal growth curves for swine are limited. Many of the curves which are available, both those for the suckling period (Mumford et al., 1923; McKenzie, 1928; Forshaw et al., 1953) and those for the period of birth to market weight (Ittner and Hughes, 1938; Nordskog, Comstock and Winters, 1944), were established many years ago. Other growth curves were established under Canadian conditions of rearing bacon-type hogs (Crampton, 1939; Ashton and Crampton, 1943; Cameron et al., 1945). Recent growth curves for Canadian Yorkshire, Lacombe, Landrace and crossbred pigs for the period of birth to weaning (Bell, 1964) suggest a faster rate of growth for pigs than was indicated by earlier workers. Work by French researchers (Aumaitre, Legault and Salmon-Legagneur, 1966) appears to be the most recent and comprehensive report on the growth pattern of the very young pig.

There appear to be no recent growth curves for pigs during the period from birth to 21 days of age established under present-day conditions in the United States. The older growth curves generally were for hogs reared under conditions different from those presently found in the United States, were based on weekly or biweekly liveweights and frequently did not present any indication of the amount of sample variation. The present study was, therefore, undertaken to establish a more detailed and complete growth curve for the very young pig based on daily weighings and containing a measure of the sample variation.
\end{abstract}

\section{Experimental Procedure}

Birthweights and daily liveweights were obtained for 87 male and 99 female Yorkshire pigs from 18 different litters in the Cornell University research herd. The pigs were farrowed during September and were housed

1 Department of Animal Science. with their dams in concrete-floored indoor pens with access to a concrete-floored outdoor runway. The sows were confined to farrowing crates for 3 days following parturition during which time they were removed once daily to receive feed and water. On the fourth day after parturition the farrowing crates were removed from the pens and the sows were fed and watered while they remained in the pen. The feed was provided ad libitum from a metal trough and consisted of a $75 \%$ corn, $10 \%$ soybean meal, $1 \%$ fish meal and $10 \%$ alfalfa meal diet fortified with vitamins, minerals, salt, and containing $13 \%$ protein. Water was available ad libitum in a cast iron trough to both the sow and the pigs. A creep feed was made available ad libitum to the pigs when they were 2 weeks of age. The male pigs were castrated when they were approximately 2 weeks old.

The average liveweights and standard deviations for days 0 through 21 were calculated and analysis of variance techniques (Steel and Torrie, 1960) were used to test litter and sex main effects and the litter $\mathrm{x}$ sex interaction effect on liveweight. The statistical arrangement for the experiment was a $2 \times 2$ factorial in which sex effects were considered fixed and litter effects considered random.

\section{Results and Discussion}

Average birthweights and daily liveweights of male and female pigs for the 3-week experimental period are presented graphically in figure 1 . The average daily liveweights of the male and female pigs did not differ significantly $(\mathrm{P}<.05)$ during the 21 days of the experiment. The average weight of the 186 pigs was $1.1,2.0,3.3$ and $5.0 \mathrm{~kg}$. at birth, 1 week, 2 weeks and 3 weeks of age, respectively. The total gain over the 3-week period as well as the pattern of growth was generally similar to that reported by Ashton and Crampton (1943), McKenzie (1928) and Forshaw et al. (1953), although the thirdweek gain obtained in the present study tended to be slightly greater that that re- 


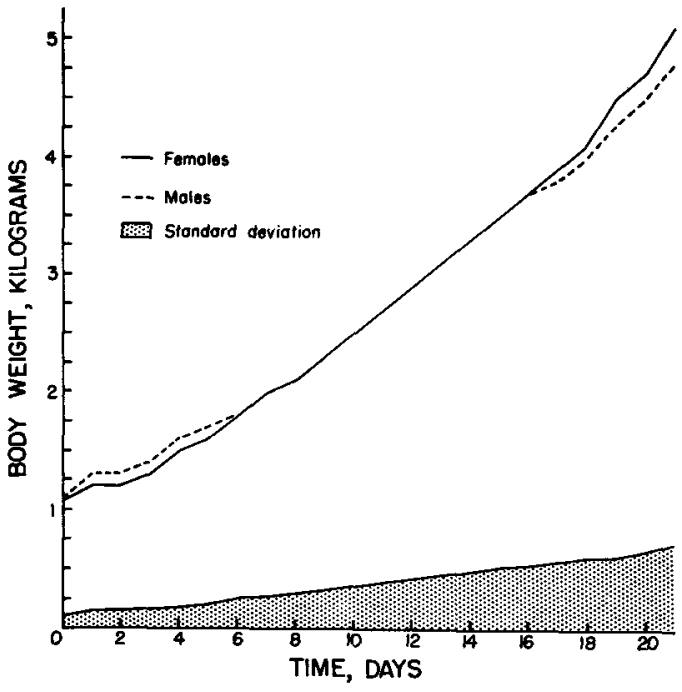

Figure 1. Growth of male and female Yorkshire pigs from birth to 21 days of age.

ported by these earlier workers. This appears to indicate that the very early growth of the young pig has not been greatly influenced by modern feeding and management practices. The standard deviation of the 186 pig sample for each of the 21 days of the experimental period is also indicated in figure 1 . The overall sample variation increased over the entire period with standard deviations of $0.12,0.27$, 0.48 and $0.74 \mathrm{~kg}$. for birth and first-, secondand third-week liveweights, respectively, for the pooled male and female observations. This variation was considerably less than that observed in the samples of Ashton and Crampton (1943) and of Forshaw et al. (1953).

Analysis of variance tests indicated significant $(\mathrm{P}<.01)$ litter effects on liveweight for all days of the experimental period. Sex effects or sex $x$ litter interaction effects generally were not significant $(\mathrm{P}<.05)$. It thus appears that sex is not an important factor in the growth of pigs at this early age, but that litter, which includes environmental as well as genetic influences, is important in determining the growth of pigs at this age. Apparently the influence of sex hormones on growth is not manifested at this early period in the life of the pig.

\section{Summary}

The birthweights and daily liveweights for 87 male and 99 female pigs reared under drylot conditions were obtained over a 3-week period and used to construct a growth curve for the very young male and female pig. Analysis of variance was used to test litter and sex main effects and the litter $\mathrm{x}$ sex interaction effect on liveweight. The daily standard deviations of the 186 pig sample were calculated and are presented in graphic form. No significant difference between the growth of male and female pigs of this young age were found. The average birth and first-, second- and third-week liveweights and standard deviations were $1.1 \pm .12,2.0 \pm .27,3.3 \pm$ .48 and $5.0 \pm .74 \mathrm{~kg}$., respectively, for the pooled male and female observations. Analysis of variance of the data indicated significant differences in growth due to litter effects for all of the 21 days of the experiment, but there was generally no significant difference due to sex and no sex $x$ litter interaction.

\section{Literature Cited}

Ashton, G. C. and E. W. Crampton. 1943. Rates of growth of bacon-type nursing pigs. Sci. Agr. 24:17.

Aumaitre, A., C. Legault and E. Salmon-Legagneur. 1966. Biometrical aspects of the growth of suckling piglets. I. Effects of sex, year of birth, size and litter parity. Ann. Zootech. 15:313.

Bell, J. M. 1964. A study of rates of growth of Yorkshire, Lacombe, Landrace, and crossbred pigs from birth to 200 pounds. Can. J. Animal Sci. 44:315.

Cameron, C. D. T., G. C. Ashton, S. A. Hilton and E. W. Crampton. 1945. Growth of bacon-type hogs. Rates of gain at specific liveweights. Sci. Agr. 25: 854.

Crampton, E. W. 1939. Growth and feed consumption of bacon hogs. Sci. Agr. 19:736.

Forshaw, R. P., H. M. Maddock, P. G. Homeyer and D. V. Catron. 1953. The growth of Duroc suckling pigs raised in drylot. J. Animal Sci. 12:263.

Ittner, N. R. and E. H. Hughes. 1938. A normal growth curve for swine. J. Heredity 29:385.

McKenzie, F. F. 1928. Growth and reproduction in swine. Mo. Agr. Exp. Sta. Res. Bul. 118:1.

Mumford, F. B., A. G. Hogan and P. M. Bernard. 1923. Growth curves of swine. Mo. Agr. Exp. Sta. Res. Bul. 62:36.

Nordskog, A. W., R. E. Comstock and L. M. Winters. 1944. Hereditary and environmental factors affecting growth rate in swine. J. Animal Sci. 3:257.

Steel, R. G. D. and J. H. Torrie. 1960. Principles and Procedures of Statistics. McGraw-Hill Book Company, Inc., New York. 